\title{
Acoustic Angiography
}

National Cancer Institute

\section{Source}

National Cancer Institute. Acoustic Angiography. NCI Thesaurus. Code C162559.

An ultrasound method for imaging blood vessels that uses dual-frequency ultrasound transducer technology to produce images with high resolution and a high contrast-totissue ratio and without significant contribution from background tissues. 